\title{
Net Impacts in Front Office IS: a First Operationalization of Delone and McLean Model in the Banking Sector
}

\author{
Sylvie Michel ${ }^{1}$, Aurélia Michaud-Trévinal ${ }^{2}$ and François Cocula ${ }^{1}$ \\ ${ }^{1}$ Univ. Bordeaux, IRGO, \\ ${ }^{2}$ La Rochelle Université, CeReGe, \\ sylvie.michel@u-bordeaux.fr \\ amichaud@uni-Ir.fr \\ Francois.cocula@u-bordeaux.fr \\ DOI: 10.34190/EJISE.19.22.2.003
}

\begin{abstract}
The variable Net Impacts, a key variable in the models for information systems evaluation, is rarely operationalized according to a rigorous method and never for the banking sector. DeLone and McLean (2016) note that the challenge of developing measures to evaluate information systems is still relevant. The measurement and conceptualization of variables in real contexts is both very important and relatively absent in the literature. This research aims at operationalizing the Net Impacts construct resulting from DeLone and McLean's (2016) evaluation model for information systems, in the specific context of retail banks. It also aims at highlighting the socio-demographic variables influencing this construct. This original work conducted with 763 people applies the Churchill paradigm (1979) to provide a reliable and valid measure of Net Impacts, inspired by the Balanced Score Card. The main result of the research concerns the empirical validation of the measure of Net Impacts. This tool consists of three categories, relating to customer satisfaction, productivity and risk and ten items, which take into account the user but also include customer perception. This three-dimensional construct shows how the information system supports the user in a wide spectrum of work. Also, by showing that in the banking field, only the function occupied by the user influences the perception of the impact of IS, we contribute to a better knowledge of the variables related to the evaluation of IS. Thus, this instrument represents a strategic tool for monitoring and guiding efforts to increase performance. The proposed instrument is very easy for $\mathrm{ClOs}$ and managers to use in order to evaluate their information systems with users.
\end{abstract}

Keywords: Business value of IT, productivity, customer satisfaction, control, Balanced Scorecard, Banking sector, DeLone and McLean model, Structural equation modelling.

\section{Introduction}

The use of computers for professional practice is now an integral part of everyday work life in organizations. Not surprisingly, the use and success of computer-based information systems has received extensive attention from researchers. As early as the 1970's, researchers tried to highlight the links between performance and IS by clearing several paths. Some have tried to show that the IS is a factor of greater productivity (Lucas, 1975; Turner, 1985; Markus and Soh, 1993; Strassman, 1997, Pashkevich and Haftor, 2014; Bui, et al., 2018). Others have tried to highlight the impact of IS on internal processes, the value chain or the creation of a competitive advantage (Parsons, 1983; Ives and Learmonth, 1984; Porter and Millar, 1985; Sethi and King, 1994; Brynjolfsson and Hitt, 1996; Drnevich and Croson, 2013; Bhatt, Wang and Rodger, 2017). Still, others attempt to understand the impact of IS on organizational performance through the notion of alignment between IS and other variables such as strategy, corporate structure or environment (Ein-Dor and Segev, 1978; 1989; Henderson and Venkatraman, 1999; Shao, 2019). Much research has been devoted to IS evaluation and to IS satisfaction (Chin and Lee, 2000; Mahmood, et al., 2000; Au, Ngai and Cheng, 2002; Vaezi, et al., 2016; Padinha and O'Neill, 2016; Lawson-Body, et al., 2017). The heterogeneity and number of constructs used to evaluate IS or its contribution to performance are therefore very numerous. On the basis of this heterogeneity of research, DeLone and McLean (1992, 2003, and 2016) proposed a synthesis in the form of a generic model that unifies the literature. They presented the Information System Success Model (ISSM), which is now widely accepted throughout the scientific community as one of the main models for evaluating IS.

The Net Impacts variable is one of the main variables in the IS evaluation models (DeLone and McLean, 2003, 2016). These authors believe that IS-related impacts can be measured at several levels - individual, organizational and societal - and recommend that all these impacts be grouped into a single variable, net impact. Thus, following Gable, Sedera and Chan (2008), DeLone and McLean (2016) argue that the challenge of

Reference this paper: Michel, S., Michaud-Trévinal, A., and Cocula, F., 2019. Net Impacts in Front Office IS: a First Operationalization of Delone and McLean Model in the Banking Sector. The Electronic Journal of Information Systems Evaluation, 22(2), pp. 92-112, available online at www.ejise.com 
developing measures to evaluate information systems is still relevant. In their view, the measurement and conceptualization of variables in real contexts remains particularly complex and little discussed in the literature.

The present research, which focuses on the banking sector, aims to respond to the challenges raised at both managerial and academic levels. Indeed, it is crucial for banks to know how account officers perceive IS impacts. For example, nearly 1.1 billion euros is the amount that BNP Paribas Bank is looking to invest to support the transformation of its Information System (IS) over the period 2017-2019. Banks, pioneers since the 1980 s in terms of investment in their information systems, keep investing massively in these systems today, because in the information age, front-office banking systems are perceived as the major strategic element of value creation and competitiveness. Also, the evaluation of information systems remains one of their major managerial problems.

How can the front office banking information system be evaluated, taking into account its specificities? How can the front office banking IS be evaluated based on the perception of the main user, the account officer? As IS has particularly influenced the way employees execute tasks, provide customer service, and communicate with one another, research is needed to identify, analyze and elaborate on the underlying dimensions of Net Impacts. Furthermore, Petter, DeLone and McLean (2012) point out that in the current era, customer focus is at the center of corporate strategy, and banks are no exception. In the banking field, it is the role of account officers to create value, supported by IS: the client-IS-account officer triad is essential (Retour, Dubois and Bobillier-Chaumon, 2006). The use, appropriation and perception of users in evaluating the IS are at the same time research themes and managerial questions (Borena and Negash, 2016; Baker, Cohanier and Leo, 2017). Yet, our literature review shows that Net Impacts variable has only rarely been operationalized and never for the banking sector. So, the net impact construct needs much further development from researchers.

The objective of this article is therefore to operationalize the Net Impacts construct from DeLone and McLean $(1992,2003$, and 2016) in the banking sector, with front office users. To this end, we extend our literature review to a set of tools to assess the Net Impacts, whether or not they are directly related, at the outset, to the ISSM model. Using the Churchill paradigm (1979), we propose a reliable and valid measure of Net Impacts construct from DeLone and McLean (1992, 2003, 2016), inspired by the Balanced Scorecard (BSC), composed of three dimensions (productivity, customer satisfaction, control) and ten items. The demographic characteristics of users are taken into account as variables of influence to determine a typical profile. As this research was carried out in the banking sector with front office IT managers, the instrument could be an operational strategic tool to monitor and guide efforts to increase IT performance.

Our paper first presents the literature review regarding the Net Impacts construct (part 2). Then, after having specified our methodological choices (part 3), we outline the procedure for creating the instrument: we start by specifying the field of construction and in particular the BSC approach, which allows us to generate a sample of items, and then present the steps to purify and validate our measuring instrument (part 4). Finally, we conclude and discuss research findings and perspectives (Part 5).

\section{Literature Review : the Net Impacts construct}

When attempting to evaluate IS, there are two main questions: Q1) which is the dependent variable, i.e. the level of evaluation or its impact on the organization? and Q2) how to measure this performance?

\subsection{The concept of Net Impacts}

Since the 1970s, researchers have sought to highlight the links between performance and IS by exploring various paths (Michel and Cocula, 2014c). Based on the heterogeneity of research, DeLone and McLean (1992) proposed a synthesis of the existing studies in the form of a generic model unifying the literature. They presented the Information System Success Model (ISSM) which is now widely recognized in the scientific community as one of the main models for IS evaluation. Yet, companies make little use of it. They refer instead to standards such as ITIL, COBIT or CMMI to ensure IS quality, monitoring of procedures or the level of IS maturity, and even its governance.

ISSM, initially composed of five variables, is multidimensional, i.e. it recognizes the success of IS as a constructed process that must include both temporal and causal influences. More specifically, in this model, 
system quality and information quality affect both IS use and user satisfaction, which in turn are the antecedents of individual impact. User satisfaction can affect use, but also, conversely, use can affect user satisfaction. Individual impacts lead to organizational impacts. In their 1992 model, DeLone and McLean use a taxonomic approach to define two levels of impact: individual and organizational. These authors proposed a new version of their model in 2003 with the aim of responding to a number of criticisms (Ballantine, et al., 1998) such as the non-operationalization of variables and the absence of empirical studies. They also responded to criticisms concerning the process-related and/or causal nature of the model, as well as the choice of variables and the links between them (dependent or independent variables). Thus, their new model includes three main changes (DeLone and McLean, 2003). First, they add as an independent variable, at the technical level, service quality provided to users. Next, they modify the variable "use" by splitting it into two sub-variables which are "intention to use" and "actual use. Finally, they believe that impacts can be measured at several levels: individual, organizational, and even societal. They prefer to group all impacts into one, called "net benefits". Ultimately, the choice of the level of impact should be determined by the researcher using the model in accordance with the context and objectives of the evaluation.

More recently, in their 2016 book, DeLone and McLean both recall the foundations of their multidimensional model and take stock of recent trends in IS evaluation. Two major changes from the 2003 model are proposed by these two authors. First, the variable "net benefits" is renamed Net Impacts. The researchers justify this change by referring to the positive aspect of the notion of profit. However, an IS can yield results that positively or negatively influence both the intention to use and user satisfaction. Second, a new feedback is introduced into their model. This presupposes that with the experience accumulated during IS use, problems and possible improvements are highlighted by users. This leads to maintenance demands that influence IS quality, data quality and service quality. In this new version (Figure 1) the authors still do not propose the operationalization of their variables and invite researchers to do so by adapting the constructs to the studied contexts.

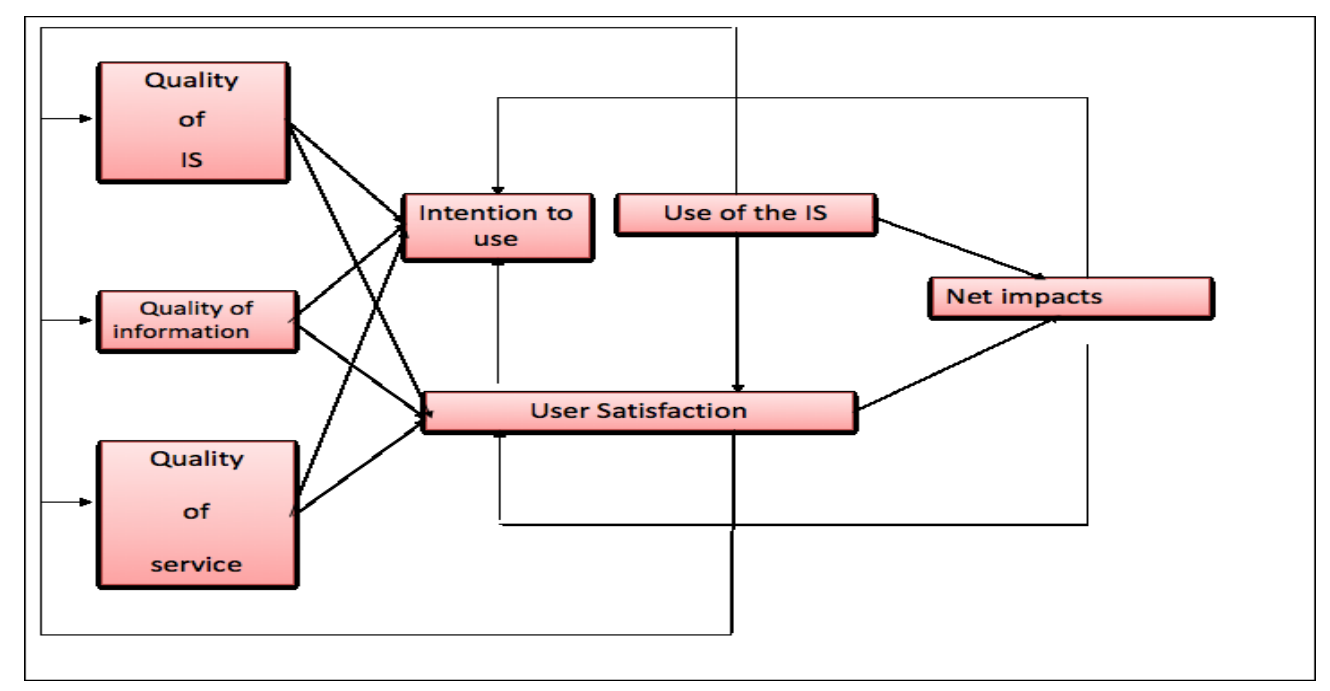

Figure 1: IS Success Model, Updated DeLone and McLean 2003 IS Success Model (modified). (2016)

\subsection{Approaches to Measuring Net Impacts:}

A review of the literature suggests several approaches to measure Net Impacts of IS. Numerous researchers have focused on specific aspects of Net Impacts, such as organizational impact (Mirani and Lederer, 1998; Bradley, Pridmore and Byrd, 2006; Acheampong and Moyaid, 2016), individual impacts (Sedera, Gable and, \& Chan, 2004; Gable, Sedera and Chan, 2008; Bravo, Santana and Rodon, 2015), individual and organizational impacts (Sedera, Eden and McLean, 2013; Alshardan, Goodwin, and Rampersad, 2016), job performance (Torkzadeh and Doll, 1999; Sun and Teng, 2017; Ul-Ain, Vaia, and DeLone, 2019), collaborative performance (Andriessen, 2012; Hsu, et al., 2012), balanced scorecard approach (Martinsons, et al., 1999; Chang and King, 2005; Lee, Chen and Chang, 2008; Chen, et al., 2015 ; Hou, 2016; Motwani and Sharma, 2016 ;. Laumer, Maier, and Weitzel, 2017). Their critical examination guides us in the choice of dimensions and certain items to be taken into account. 
In this way, one of these approaches, proposed by Mirani and Lederer (1998), focuses on the organizational benefits of IS projects. The authors propose a measurement of organizational impacts and suggest three categories: strategic benefits that are measured by competitive advantage, alignment and customer relations; information benefit measured by information access, information quality and information flexibility; and finally transactional benefits measured by communications efficiency, system development efficiency and business efficiency. Similarly, Bradley, Pridmore and Byrd (2006), in an attempt to contextualize the ISSM, propose three levels of impacts related to the use of the SI: strategic, tactical and operational. These instruments are not suitable for our research because these organizational impact assessments, determined by IS projects, seem to us to be too focused on application developers and not enough on end users, or even decision makers. We aim to assess the perception of Net Impacts among retail bank account officers. Moreover, the informational impacts dimension is already present in ISSM, through the variable "quality of information", which is considered in the ISSM as a determinant of Net Impacts and not as one of its dimensions.

In a second approach, that of Torkzadeh and Doll (1999), starts out from the observation, accepted by both the literature and managers, that IS success can be measured by its impact on the work of end users. The authors develop an instrument with four dimensions. The first is task productivity, i.e. the extent to which an application increases the user result per unit of time ( 3 items). The second dimension is task innovation, which reports on the extent to which an application helps users to create or find new ideas for their work (3 items). The third is customer satisfaction, which measures the extent to which an application helps the user create value for the internal or external customer ( 3 items). Finally, the last one looks at management control, which examines to what extent an application helps to regulate the work process and performance ( 3 items). Doll, Koufteros and Torkzadeh (2005) provide a statistical confirmation of this instrument's validity. However, it does not appear to be entirely appropriate for our field of research either. Indeed, while the user satisfaction and productivity task dimensions appear to be very relevant to the banking sector, the innovation task and management control dimensions are not appropriate for measuring the impacts of banking information systems, since these tasks are not devolved to account officers.

Another interesting approach is the BSC, an instrument originally developed by Kaplan and Norton (1992) and adapted to the generic assessment of IS (Martinsons and Davison, 1999; Milis and Mercken, 2004; Chang and King, 2005; Epstein and Rejc, 2005; Fang and Lin, 2006; Ebrahimi, et al, 2013, Lee, Chen and Chang, 2008), and also adapted to much more specific evaluations such as ERPs (Rosemann and Wieses, 1999; Chand, et al., 2005; Fang and Lin, 2006; Motwani and Sharma, 2016), investment in information technology (Ahmad, 2014; Wu and Chen, 2014), or software in SaaS (Lee, Park and Lim, 2013), IS governance (Van Gremberge and De Haes, 2005), CRM (Kim, Suh and Hwang, 2003), e-commerce (DeLone and McLean, 2004), Business intelligence (Hou, 2016). The BSC model is based on the idea that performance should be assessed from four main perspectives: financial, customer, internal business, and innovation and learning. The name of this instrument indicates the authors' willingness to strike a "balance" between the long and the short term, between financial and non-financial measures, between internal and external perspectives. Initially, the authors presented the BSC as a tool for clarifying and communicating strategy and gradually developed it into a basis for strategic management (Kaplan and Norton, 1992). Martinsons and Davison (1999) propose a model based on the conceptual framework of the BSC, in order to evaluate either a particular application, an IS department, or IS as a whole. They brought significant changes to the outlook, but also to the measurements with respect to the Kaplan and Norton (1992) instrument.

In this adaptation of the BSC to IS, the main perspectives are as follows:

User orientation perspective: the main question is whether the services provided by the IS meet the needs of users; the objectives are to establish and maintain a good image and reputation with users so that the IS (and the IS department) is perceived as the preferred service provider, it can be used to exploit the opportunities related to IS, and it satisfies the needs of users.

Internal process perspective: the mission is to deliver IT services efficiently and effectively. It is therefore necessary to anticipate users' requests, to be efficient in terms of application development and planning, application maintenance, malfunction management, and acquisition of new technologies in the field of hardware and software. 
Business value perspective: the key question is whether IS accomplishes its objectives and contributes to creating value for the whole organization. The objectives then revolve around controlling the costs of IS, selling IT services to third parties, and ensuring that IS projects create value.

Future readiness perspective: this involves preparing for the challenges of the future and preparing for potential changes. The objectives are linked to the anticipation of problems, the updating of tools such as applications and hardware, business continuity and user training.

Furthermore, Chang and King (2005) propose an instrument (Information System Functional Scorecard) comprising three dimensions: systems performance, service performance and information effectiveness. Their systems performance variable measures the intrinsic system's qualities (reliability, accessible, etc.), but also the system's impacts on users' work, impacts on internal processes, impacts on learning and knowledge, and impacts on external constituencies (customers and suppliers). This brings us back to the main dimensions of the BSC. The authors carry out an operationalization of their variables and validation of their instrument. It should be noted that their instrument, like that of Mirani and Lederer (1998), encompasses dimensions already present in the ISSM model (quality of system and service). So it would be redundant in our study.

Thus, despite their interest, none of these instruments can be used in their present state as an instrument to measure the Net Impacts of IS, for four main reasons.

The first is that these three main instruments have not been operationalized for a particular context or even tested at all (Martinsons and Davison, 1999). However, the banking sector and the banking information system are specific (Michel and Cocula, 2014b), requiring a specific measurement instrument. For DeLone and McLean (2016), the "context" directly influences the Net Impacts of IS. To date, most research on the success of IS has measured Net Impacts using financial indicators. However, the latter consider only a small part of the Net Impacts of IS (DeLone and McLean, 2016, p.74). To answer this question and adopting a more holistic approach, Scott, et al. (2015) cite four contextual forces that can influence measures of success: IT evolutions; the primacy of the user; the definition of value; the rationale and uses of IS.

In addition, the three main instruments presented do not accurately measure the concept of Net Impacts as we have defined it. For one, our concept is a measure of the impact of Information Technologies. Additionally, it is an evaluation of IS performance.

Furthermore, it concerns organizational impacts related to IS projects. In addition, the Net Impacts variable is part of the ISSM model, a multidimensional model that captures several constructs and antecedents. However, we have noted that in the dimensions proposed by the three instruments presented, some of them correspond to variables in the ISSM model, such as service quality, information quality or system quality. We therefore cannot use one of these instruments because they propose a measure already incorporated in the net impact antecedent variables in ISSM. Also, the three instruments presented remain vague as to the evaluators' identity. Are they the designers/developers? The CIO? External consumers? End users?

Finally, our review of the literature confirms the need to operationalize the Net Impacts of ISSM in the banking sector. While we can partially use the dimensions stemming from previous approaches, it is necessary to create an ad hoc structure, a contextualized instrument in the banking sector. We propose a synthesis of the literature on measures of Net Impacts of IS in table 1.

Table 1: Synthesis of the literature on measures of Net Impacts of IS

\begin{tabular}{|c|c|c|c|c|}
\hline $\begin{array}{l}\text { Authors } \\
\text { and Year }\end{array}$ & $\begin{array}{l}\text { Evaluation of } \\
\text { Net Impacts }\end{array}$ & $\begin{array}{l}\text { Measuring } \\
\text { instrument } \\
\text { Dimensions }\end{array}$ & Items & $\begin{array}{l}\text { For example, } \\
\text { used by }\end{array}$ \\
\hline $\begin{array}{l}\text { Mirani and } \\
\text { Lederer } \\
(1998)\end{array}$ & $\begin{array}{l}\text { Evaluation of } \\
\text { the } \\
\text { organizational } \\
\text { impacts of IS } \\
\text { projects }\end{array}$ & $\begin{array}{l}\text { Three categories: } \\
\text { 1) Strategic benefits } \\
\text { 2) Informational } \\
\text { benefits } \\
\text { 3) Transactional } \\
\text { benefits }\end{array}$ & $\begin{array}{l}\text { 25 items: } \\
\text { 1) } 8 \text { items } \\
\text { 2) } 7 \text { items } \\
\text { 3) } 10 \text { items }\end{array}$ & $\begin{array}{l}\text { Amoako- } \\
\text { Gyampah and } \\
\text { Salam, (2004); } \\
\text { Bradley, Pridmore } \\
\text { and Byrd, (2006); } \\
\text { Motwani and } \\
\text { Sharma (2016); } \\
\text { Acheampong, and }\end{array}$ \\
\hline
\end{tabular}




\begin{tabular}{|c|c|c|c|c|}
\hline $\begin{array}{l}\text { Authors } \\
\text { and Year }\end{array}$ & $\begin{array}{l}\text { Evaluation of } \\
\text { Net Impacts }\end{array}$ & $\begin{array}{l}\text { Measuring } \\
\text { instrument } \\
\text { Dimensions } \\
\end{array}$ & Items & $\begin{array}{l}\text { For example, } \\
\text { used by }\end{array}$ \\
\hline & & & & Moyaid, (2016) \\
\hline $\begin{array}{l}\text { Torkzadeh } \\
\text { and Doll } \\
(1999)\end{array}$ & $\begin{array}{l}\text { Perceived } \\
\text { impact of } \\
\text { Information } \\
\text { Technology on } \\
\text { the work of } \\
\text { end users. }\end{array}$ & $\begin{array}{l}\text { Four categories: } \\
\text { 1. Task productivity } \\
\text { 2. Task innovation } \\
\text { 3. Customer } \\
\text { satisfaction } \\
\text { 4. Management } \\
\text { control }\end{array}$ & $\begin{array}{l}\text { 12 items: } \\
\text { 1) } 3 \text { items } \\
\text { 2) } 3 \text { items } \\
\text { 3) } 3 \text { items } \\
\text { 4) } 3 \text { items } \\
\text { Items and structure confirmed } \\
\text { by Doll et al. (2005) }\end{array}$ & $\begin{array}{l}\text { Ul-Ain, Vaia, and } \\
\text { DeLone, (2019); } \\
\text { Sun and Teng. } \\
\text { (2017) }\end{array}$ \\
\hline $\begin{array}{l}\text { Martinsons } \\
\text { et al. } \\
\text { (1999) }\end{array}$ & $\begin{array}{l}\text { Balanced } \\
\text { Scorecard } \\
\text { model applied } \\
\text { to IS (untested } \\
\text { model) }\end{array}$ & $\begin{array}{l}\text { Four categories: } \\
\text { 1) Business value } \\
\text { perspective } \\
\text { 2) User orientation } \\
\text { perspective } \\
\text { 3) Internal process } \\
\text { perspective } \\
\text { 4) Future readiness } \\
\text { perspective }\end{array}$ & $\begin{array}{l}\text { The dimensions are broken } \\
\text { down: } \\
\text { 1) Business Value: Cost } \\
\text { control ( } 4 \text { items); Sales to } \\
\text { third parties (1 item), } \\
\text { Business value of an IT } \\
\text { project ( } 8 \text { items), Risks (7 } \\
\text { items); Value of an IS } \\
\text { department ( } 3 \text { items) } \\
\text { 2) User: Be the preferred } \\
\text { supplier for applications and } \\
\text { operations building and } \\
\text { maintaining relationships with } \\
\text { the user community; } \\
\text { satisfying end-user needs } \\
3 \text { ) Internal process: Planning } \\
\text { (1 items); Development (4 } \\
\text { items); Operations ( } 2 \text { items) } \\
4 \text { ) Readiness perspective: IT } \\
\text { specialists capabilities (4 } \\
\text { items); Perceived satisfaction } \\
\text { of IS employees ( } 2 \text { items); } \\
\text { Portfolio of applications (4 } \\
\text { items); Research on } \\
\text { emerging technologies (2 } \\
\text { items) }\end{array}$ & $\begin{array}{l}\text { Lee, Chen and } \\
\text { Chang, (2008); } \\
\text { Wu, and Chen, } \\
(2014) ; \text { Hou, } \\
\text { (2016); Motwani } \\
\text { and Sharma, } \\
\text { (2016) }\end{array}$ \\
\hline $\begin{array}{l}\text { Chang and } \\
\text { King } \\
(2005)\end{array}$ & $\begin{array}{l}\text { Evaluating the } \\
\text { performance } \\
\text { of IS through a } \\
\text { functional BSC }\end{array}$ & $\begin{array}{l}\text { Three categories: } \\
\text { 1) System } \\
\text { performance ( } 6 \text { sub- } \\
\text { dimensions) } \\
\text { 2) Information } \\
\text { effectiveness ( } 7 \text { sub } \\
\text { dimensions) } \\
\text { 3) Service } \\
\text { performance (5 sub- } \\
\text { dimensions) }\end{array}$ & $\begin{array}{l}67 \text { items: } \\
\text { 1) } 31 \text { items } \\
\text { 2) } 20 \text { items } \\
\text { 3) } 16 \text { items }\end{array}$ & $\begin{array}{l}\text { Chen, et al., } \\
\text { (2015); Laumer, } \\
\text { Maier and Weitzel } \\
\text { (2017) }\end{array}$ \\
\hline $\begin{array}{l}\text { Sedera, } \\
\text { Eden and } \\
\text { McLean } \\
\text { (2013) }\end{array}$ & $\begin{array}{l}\text { Individual } \\
\text { and/or } \\
\text { organizational } \\
\text { impact }\end{array}$ & $\begin{array}{l}\text { 1) Individual impact } \\
\text { 2) Organizational } \\
\text { impact }\end{array}$ & $\begin{array}{l}\text { 1) } 4 \text { items } \\
\text { 2) } 8 \text { items }\end{array}$ & $\begin{array}{l}\text { Alshardan, } \\
\text { Goodwin and } \\
\text { Rampersad, } \\
\text { (2016), Bravo, } \\
\text { Santana and } \\
\text { Rodon, (2015) }\end{array}$ \\
\hline
\end{tabular}

\section{Methodology}

The data used to test our hypotheses were collected from the principal French retail banks. We decided to operationalize the variables and to test our model with account officer users of front office IS. We detail below the context of empirical research and the data collection

\subsection{Conceptualization of the construct: the Churchill paradigm}

The definition of constructs plays a fundamental role in science (MacKenzie, 2003). The development of a coherent, robust and generalizable theory requires well-defined constructs; otherwise, the credibility of the results is called into question (Summers, 2001). Several studies have investigated the various approaches to measurement (e. g. Lee and Hooley, 2005; Salzberger and Koller, 2013). We have chosen to use the 
methodological approach developed by Churchill (1979) called the "Churchill paradigm", which is part of the classical theory of scores. The model presented here is a second-order model. We seek to accurately evaluate each dimension of the constructed Net Impacts in a rigorous way, so that managers can also measure each dimension separately. These are considered latent variables that have reflexive relationships to the items. It is therefore a type II construct, i.e. a first-order multi-dimensional reflexive and second-order formative construct. That is why we have chosen to use the Churchill paradigm to operationalize this construct.

\subsection{Context of the empirical research}

Five of the six biggest banks in France agreed to be partners in our study. We started with an exploratory phase by conducting interviews in these banks. We had the opportunity to "test" the work stations of the different actors (reception, individual account officer, etc.) of the five banks and to interview account officers, agency directors, some CIOs and organizational managers. We can say that the account officer is a professional whose main activity is primarily to provide clients with advice on the banking services offered. Business is fastchanging, notably due to competitive pressure, but also to the arrival of new technologies such as multichannel and internet banking. Competitive pressure is manifested by a stronger emphasis on short-term objectives. It is necessary to increase net banking income for each family of customers, build customer loyalty, direct them to the right communication channel, etc. From an adviser, the customer service representative has become a salesperson (Des Garets, Paquerot and Sueur, 2009). This change in the profession is accompanied by an evolution of skills. Today, account officers must be able to describe a large number of products (banking or otherwise, such as home services, insurance services, mobile telephony) and manage a very large portfolio of clients. It should also be noted that the multi-channel capability has changed the job of customer account officer. It has reduced the number of opportunities for client-advisor meetings (Des Garets, Paquerot and Sueur, 2009). In this respect, the account officer plays a key role. They are subject to strong competitive pressure, with sales targets driven upwards by the hierarchy, and must constantly adapt to the new behaviour of bank users.

As part of their activities, the account officer relies on and interacts with the front-office IS. Their working environment is therefore organized around a computer workstation, composed of several application layers representing their "business environment", an intranet and sometimes Internet access which is more or less limited depending on the establishment. Depending on the bank, the presentation of the desktop (i.e. access to the various functionalities) is of course different. However, it is possible to establish a typology of the workstation, in that it is personalized according to the function occupied. Thus, each account officer has a space on his workstation that is adapted to the various business lines, enabling him to manage customer relations both operationally and analytically, for example contract management, customer knowledge history (civil status, savings, products, appointment history, etc.). It is also in this business area that sales representatives can find all information relating to products, markets, regulations and arguments. The account officers also have an intranet reporting on the social life of the company and providing access to certain support functions (HR online service, etc.) and a messaging service and agenda.

\subsection{Data collection}

In line with the recommendations of Churchill (1979), most of the items used in this study have been taken from the literature. In addition, in order to fill the gaps in the literature concerning the constructs specific to banking IS, interviews were held with retails bank account officers and branch manager.

\subsubsection{A qualitative exploratory phase}

Series of interviews composed the qualitative exploratory phase. Open interviews were conducted with the $\mathrm{CIOs}$ of three banks in order to gain an insight into the general functioning of the banking system and cultural norms. Then, thirteen semi-structured interviews of four different banks' users were conducted (table 2). The objective was to learn about the uses of the SI, expectations, obstacles, motivation, etc. The analysis of the semi-structured interviews was carried out in two stages. First, we compiled an analysis grid and then all interviews were transcribed and analyzed with Alceste software. This lexical analysis software makes it possible to identify the main lexical worlds relative to the perception of SI success and the strongest significant structures. 
Table 2: Number and profession of users interviewed

\begin{tabular}{|l|l|}
\hline Interviewees' professions & Number of interviewees \\
\hline Head of bank branch & 5 \\
\hline Bank reception consultant & 3 \\
\hline Account officer for private customers & 3 \\
\hline Account officer for professional customers & 2 \\
\hline TOTAL & 13 \\
\hline
\end{tabular}

In addition with a literature review, analysis of the interviews enabled us to generate a sample of items.

\subsubsection{Quantitative data collection}

Two rounds of data collection were performed by means of an online questionnaire sent to two retail banks. For both data collections, we had a comprehensive sampling frame (at the regional level) and also had all mail addresses. So we set up an online survey, sent by e-mail to the whole sample. We posted our questionnaire on a website and invited respondents to visit the site.

For the first round, the questionnaire was sent to the entire set of email addresses in the sales network: 571 persons in all. We obtained a return rate of $36.6 \%$ (209 responses). This first round of data collection took place over a period of one week, followed by an exploratory factor analysis.

For the second round of data collection, we had access to the entire set of branch email addresses: 550 persons. The questionnaire was available online for a period of two weeks, with two reminders, coordinated by the Quality Manager. The return rate was 36.7\%, i.e. 202 responses (192 responses). We performed a confirmatory factor analysis and were able to test our hypotheses using this second collection of data. Table 3 summarizes the different stages of our approach stemming from the Churchill paradigm (1979).

Table 3: Research Steps: Measuring Instrument Development and Validation Processes - adapted from Churchill (1979) and MacKenzie, Podsakoff and Podsakoff (2011)

\begin{tabular}{|c|c|}
\hline Steps of the process & Methods used \\
\hline $\begin{array}{l}\text { Step 1: Specify the domain of the } \\
\text { construct }\end{array}$ & $\begin{array}{l}\text { Literature review on the construct Net Impacts. Identification of } \\
\text { three main approaches. }\end{array}$ \\
\hline $\begin{array}{l}\text { Step 2: Generate a sample of items } \\
\text { and ensure content validity }\end{array}$ & 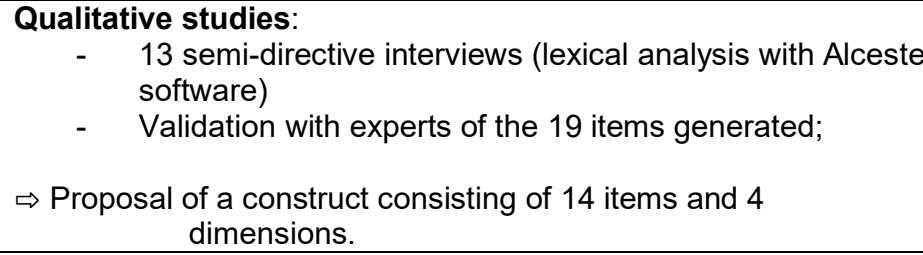 \\
\hline Step 3: Data collection & $\begin{array}{l}\text { Self-administered online questionnaire from } 571 \text { bank agents. } \\
\quad \text { Return rate } 36 \% \text {. } \\
(n=271)\end{array}$ \\
\hline $\begin{array}{c}\text { Step 4: Specify and purify the } \\
\text { measurement model }\end{array}$ & $\begin{array}{l}\text { First purification of the measuring instrument (exploratory } \\
\text { Cronbach alpha and principal component factorial analyses) }\end{array}$ \\
\hline Step 5: Data collection & $\begin{array}{l}\text { - } \quad \text { Return to literature; } \\
\text { - } \quad \text { Second data collection using an online questionnaire } \\
\text { from } 550 \text { agents of another bank. Return rate } 37 \% . \\
(n=192)\end{array}$ \\
\hline $\begin{array}{c}\text { Step 6: Validation of the measuring } \\
\text { instrument (new sample) }\end{array}$ & $\begin{array}{ll}\text { - } & \text { Validation of the measuring instrument: (confirmatory } \\
& \text { factor analysis) } \\
\text { - } & \text { Convergent validity and discriminatory validity; } \\
\text { - } & \text { Second order construct with formative indicators: } \\
& \text { multicollinearity test, verification of the three dimensions, } \\
& \text { nomological validity. }\end{array}$ \\
\hline
\end{tabular}




\section{Development of the construct and validation of the measurement instrument}

In this part, we first present the results of the exploratory and confirmatory factor analyses performed on the construct and realized with SPSS and AMOS.

\subsection{Generation of a sample of items}

We operationalize the construct in the context of the front office Information System of these large retail banks. Once the construct scope has been delineated through the literature review, the next step is to generate items that can describe the whole concept (MacKenzie, Podsakoff and Podsakoff, 2011). In order to operationalize the Net Impacts construct of front office banking, we have chosen as the main theoretical framework the dimensions proposed by both the BSC and the Torkzadeh and Doll (1999) instrument. This theoretical basis has been enriched by the results of our qualitative exploratory analysis.

\subsubsection{Results of qualitative analysis}

The first element emerging from these interviews is that the IS is perceived as a tool that business managers must be able to use to improve relations with clients. Far from being seen as a tool interposed between them and the client thus reinforcing a transactional approach, the IS is clearly perceived as confirming the relational approach during appointments. The second point to note is that while the IS is seen as an indispensable, relevant, useful and value-creating tool, expectations appear to exceed achievements. Next, four main themes emerge from our qualitative analysis of the perceived Net Impacts. The analysis of the interviews revealed impacts related to productivity, learning impacts, customer satisfaction impacts, strategic and even organizational impacts, mainly linked to risk controls (limitation of operational risks or compliance with procedures and regulations).

\subsubsection{Questionnaire development}

For the precise formulation of the items, we drew on the literature and the results of the qualitative analysis, which enabled us to propose 19 items. Our set of items was submitted to five researchers and two $\mathrm{ClOs}$ from the banking sector. Five items were deleted, mainly because of their wording, which was redundant in relation to others, or because of their low interest, according to experts. Some of them were modified and rewritten. We therefore retain a set of fourteen items to measure the net perceived impacts, classified into four main dimensions (detailed in table 5 below): a "customer satisfaction perspective" dimension consisting of three items; a "productivity perspective" dimension (internal process) consisting of seven items; a "learning perspective" dimension consisting of one item; and a "control perspective" dimension consisting of three items. In addition, one of the objectives is to determine whether socio-demographic differences between users have an influence on the assessment they make. Highlighting a user profile with a better perception is also a theoretical objective of this work (Petter, DeLone and McLean, 2013). This questionnaire was thus completed by five socio-demographic identification questions concerning the respondents' age (20-29 years old, 30-39, 40-49, 50-59, 60 years old and over), gender (women or men), occupation (reception, account officer for private customers, account officer for professional customers, wealth management account officer, branch manager), level of education (National Diploma, Baccalaureate, second-year university level, fourthyear university level, Master's degree level) and seniority in the bank (less than one year, from 1 year to 2 years, from 3 years to 5 years, from 6 years to 10 years, more than 10 years). All questions were formulated in the form of a five-position Likert scale.

Table 5: Dimensions and items of Net Impacts

\begin{tabular}{|c|c|c|}
\hline Dimensions & Items /(code bracketed) & Adapted from literature or new ones \\
\hline \multirow[t]{3}{*}{$\begin{array}{l}\text { customer } \\
\text { satisfaction } \\
\text { perspective } \\
\text { dimension }\end{array}$} & $\begin{array}{l}\text { 1. My information system improves } \\
\text { customer satisfaction. (Isatclt) }\end{array}$ & $\begin{array}{l}\text { Torkzadeh and Doll (1999); Grover and Davenport } \\
\text { (2001); Van Grembergen, Saull and De Haes } \\
\text { (2003); Kim, Suh and Hwang, (2003); Chand et al. } \\
\text { (2005); Epstein and Rejc, (2005); Fang and Lin } \\
\text { (2006), Hou, (2015) }\end{array}$ \\
\hline & $\begin{array}{l}\text { 2. My information system improves } \\
\text { customer service. (Iservclt) }\end{array}$ & $\begin{array}{l}\text { Torkzadeh and Doll (1999); Grover and Davenport } \\
\text { (2001); Van Grembergen, Saull and De Haes } \\
\text { (2003); Kim, Suh and Hwang, (2003); Lee, Park } \\
\text { and Lim, (2013); Hou, (2015) }\end{array}$ \\
\hline & $\begin{array}{l}\text { 3. My information system allows me } \\
\text { to convey a better image to clients. } \\
\text { (limage) }\end{array}$ & $N E W$ \\
\hline productivity & 4. My information system saves me & Mirani and Lederer (1998); Torkzadeh and Doll \\
\hline
\end{tabular}




\begin{tabular}{|c|c|c|}
\hline Dimensions & Items /(code bracketed) & Adapted from literature or new ones \\
\hline \multirow[t]{7}{*}{$\begin{array}{l}\text { perspective" } \\
\text { dimension } \\
\text { (internal } \\
\text { process }\end{array}$} & time. (Itps) & $\begin{array}{l}\text { (1999); Murphy and Simon (2002); Van } \\
\text { Grembergen, Saull and De Haes (2003); Chand et } \\
\text { al. (2005); Fang and Lin (2006); Lee, Park and } \\
\text { Lim, (2013); Ahmad (2014), Sun and Teng (2017) }\end{array}$ \\
\hline & $\begin{array}{l}\text { 5. My information system simplifies } \\
\text { my work. (Isimplw) }\end{array}$ & Chang and King (2005); Fang and Lin (2006) \\
\hline & $\begin{array}{l}\text { 6. My information system allows me } \\
\text { to make better decisions. (Idec) }\end{array}$ & $\begin{array}{l}\text { Mirani and Lederer (1998); Murphy and Simon } \\
\text { (2002); Chang and King (2005); Chand et al. } \\
\text { (2005), Alshardan, Goodwin and Rampersad. } \\
\text { (2016). }\end{array}$ \\
\hline & $\begin{array}{l}\text { 7. My information system improves } \\
\text { my quality of life at work. (Iqualviw) }\end{array}$ & $\begin{array}{l}\text { Chang and King (2005); Van Grembergen, Saull } \\
\text { and De Haes (2003) }\end{array}$ \\
\hline & $\begin{array}{l}\text { 8. My information system improves } \\
\text { the quality of my work. (lqualw) }\end{array}$ & $\begin{array}{l}\text { Goodhue and Thompson (1995); Torkzadeh and } \\
\text { Doll (1999); Murphy and Simon (2002); Van } \\
\text { Grembergen, Saull and De Haes (2003); Chang } \\
\text { and King (2005); Ahmad (2014); Hou, (2015) }\end{array}$ \\
\hline & $\begin{array}{l}\text { 9. My information system improves } \\
\text { communication within my company. } \\
\text { (Icomm) }\end{array}$ & Chang and King (2005); Ahmad (2014) \\
\hline & $\begin{array}{l}\text { 10. My information system allows } \\
\text { me to organize myself better. (lorg) }\end{array}$ & $\begin{array}{l}\text { Van Grembergen, Saull and De Haes (2003); } \\
\text { Chang and King (2005); Chand et al. (2005) }\end{array}$ \\
\hline $\begin{array}{l}\text { learning } \\
\text { perspective" } \\
\text { dimension }\end{array}$ & $\begin{array}{l}\text { 11. My information system allows } \\
\text { me to learn. (lappr) }\end{array}$ & $\begin{array}{l}\text { Van Grembergen et al. (2003); Chang and King } \\
\text { (2005); Lee, Park and Lim, (2013); Ahmad (2014), } \\
\text { Alshardan, Goodwin and Rampersad, (2016). }\end{array}$ \\
\hline \multirow[t]{3}{*}{$\begin{array}{l}\text { "control } \\
\text { perspective" } \\
\text { dimension }\end{array}$} & $\begin{array}{l}\text { 12. My information system allows } \\
\text { me to increase my company's net } \\
\text { banking income. (Ipnb) }\end{array}$ & Chang and King (2005) \\
\hline & $\begin{array}{l}\text { 13. My information system enables } \\
\text { me to better control operational risk. } \\
\text { (Irisqop) }\end{array}$ & NEW \\
\hline & $\begin{array}{l}\text { 14. My information system makes it } \\
\text { easier to comply with regulations. } \\
\text { (Irglmt) }\end{array}$ & NEW \\
\hline
\end{tabular}

Before collecting the data, it is recommended to specify the measurement model (Mackenzie, Podsakoff and Podsakoff, 2011) to ensure that it is well adapted to a multi-dimensional construct, as the constructs are not reflective or formative in nature. In this research, the model used is a formative model; the analyzed construct is composed of several dimensions, each representing a facet of the construct. Social scientists are encouraged to use such models, which allow the analysis of complex constructs in second-order variables (Bèzes, 2014). Formative models explain more variance than reflective models, which increases their predictive power (Finn and Wang, 2014). The conceptualized Net Impacts model is formalized in Figure 2 below.

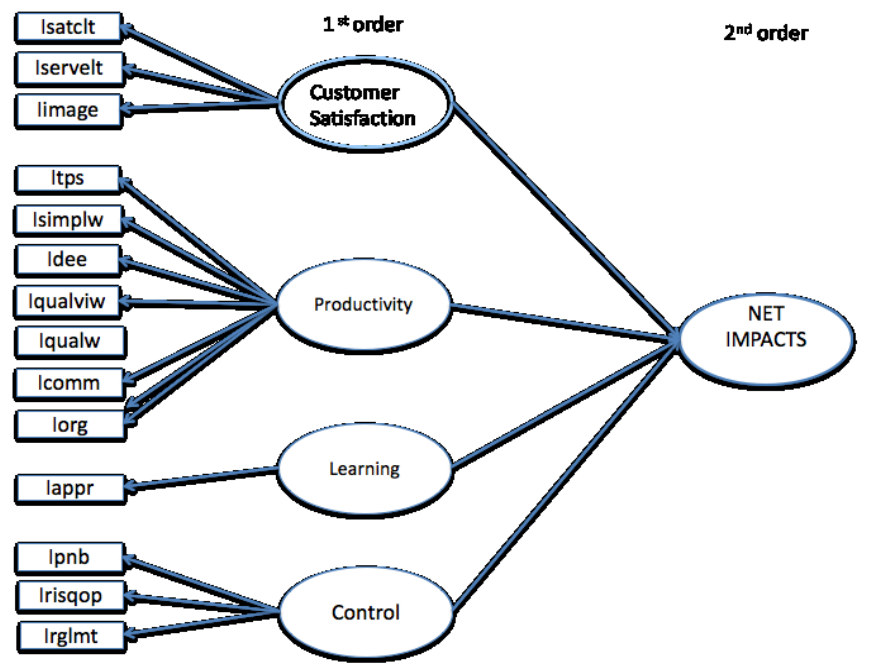

Figure 2: Conceptual Model of Net Impacts 
Secondly, we verify the reliability and validity of this instrument by conducting an exploratory factor analysis, with SPPS software.

\subsection{Exploratory analysis of the scale}

At this stage, an initial data collection is necessary to purify our measuring instrument represented by our questionnaire. A second data collection will be necessary to ensure the reliability and validity of our measurement instrument. These are steps 3, 4 and 5 of the Churchill paradigm (1979). These two collections of quantitative data were compiled using an online questionnaire. The breakdown of employees in the network by function is reproduced in Appendix $A$.

We conducted two exploratory factorial principal component analyses (AFEs) on our two data collections, as they are intended to identify the underlying explanatory dimensions of the results obtained on a scale. Our data are metric and factorizable. The Kaiser, Meyer, Olkin (KMO) and Bartlett's sphericity tests are positive and very satisfactory for both data collections $(0.875 / 0.864)$ and allow us to verify the ability of the data to be factorized. The correlation anti-image matrix provides indices all greater than 0.60 . The reliability of our scale is good with a Cronbach alpha of 0.888 and 0.887 respectively for the two data collections. The exploratory factorial analysis on the second data collection provides us with the same structure: two main dimensions that are productivity and control, and only one item with a somewhat low quality of representation (lorg) which will be excluded in this second exploratory factorial analysis. We obtain a constructed structure consisting of ten items and two dimensions. The variance explained by these two dimensions (ten items) is acceptable (greater than 60\%).

Table 5: Main results of exploratory factorial analyses in principal components, Net Impacts

\begin{tabular}{|c|c|c|c|c|c|c|c|c|c|c|}
\hline \multicolumn{11}{|c|}{ Net Impacts } \\
\hline \multirow[t]{3}{*}{ Items } & \multicolumn{2}{|c|}{ Quality of representation } & \multicolumn{6}{|c|}{ Factorial Contribution } & \multirow{3}{*}{\multicolumn{2}{|c|}{ Alpha }} \\
\hline & \multirow[b]{2}{*}{ Collection 1} & \multirow[b]{2}{*}{ Collection 2} & \multicolumn{3}{|l|}{ Dimension 1} & \multicolumn{3}{|c|}{ Dimension 2} & & \\
\hline & & & Collection 1 & \multicolumn{2}{|c|}{ Collection 2} & \multicolumn{2}{|c|}{ Collection 1} & Collection 2 & & \\
\hline Isimplw & 0,694 & 0,555 & 0,832 & \multicolumn{2}{|l|}{0,720} & & & & \multirow{9}{*}{$\begin{array}{l}0,888 \\
/ \\
0,887\end{array}$} & \multirow{11}{*}{$\begin{array}{l}0,881 \\
/ \\
0,886\end{array}$} \\
\hline Iqualw & 0,656 & & 0,764 & \multicolumn{2}{|l|}{0,725} & & & & & \\
\hline Itps & 0,555 & 0,621 & 0,742 & \multicolumn{2}{|l|}{0,786} & & & & & \\
\hline Iqualviw & 0,551 & 0,579 & 0,741 & \multicolumn{2}{|l|}{0,688} & & & & & \\
\hline lorg & 0,5 & 0,496 & & & & & & & & \\
\hline limage & 0,524 & 0,591 & 0,655 & \multicolumn{2}{|l|}{0,759} & & & & & \\
\hline Isatclt & 0,559 & 0,56 & 0,613 & \multicolumn{2}{|l|}{0,728} & & & & & \\
\hline Idec & 0,569 & 0,531 & 0,572 & \multicolumn{2}{|l|}{0,553} & & & & & \\
\hline Iservclt & 0,528 & 0,545 & 0,544 & \multicolumn{2}{|l|}{0,698} & & & & & \\
\hline Irisqop & 0,708 & 0,774 & & & & 0,846 & & 0,873 & \multirow{2}{*}{$\begin{array}{l}0,759 \\
/ \\
0,721\end{array}$} & \\
\hline Irglmt & 0,715 & 0,715 & & & & 0,842 & & 0,813 & & \\
\hline \multicolumn{3}{|c|}{ Valeur propre } & $5,097 / 4,98$ & & & \multicolumn{3}{|c|}{$1,51 / 1,16$} & \multicolumn{2}{|c|}{$\begin{array}{l}\mathrm{KMO}=0,875 \\
/ 0,864\end{array}$} \\
\hline \multicolumn{3}{|c|}{ Bartlett's Test : Significatif } & \multicolumn{6}{|l|}{ Varimax } & \multicolumn{2}{|c|}{$P=0,000$} \\
\hline \multirow{2}{*}{\multicolumn{3}{|c|}{ Variance explained in \% }} & \multicolumn{2}{|l|}{$46,33 / 49,8$} & \multicolumn{2}{|c|}{$\begin{array}{ll}13,73 \\
11,645\end{array}$} & $\mathrm{~N}=2$ & 09 & $\mathrm{~N}=$ & $=192$ \\
\hline & & & $60 / 61,534$ & & & & & & & \\
\hline
\end{tabular}

\subsection{Validation and confirmation of the measurement scale}

Our goal is now to confirm our measurement instrument (step 6 of the Churchill paradigm). Factor analysis can be used in a confirmatory logic to test predefined assumptions. It aims to compare assumptions about latent variables and their indicators with empirical data. Confirmatory analyses are based on models of structural equations that include observable variables (statements of scales), latent variables (theoretical constructs) and the difference between the two, i.e., error (Bentler and Bonett, 1980; Brown and Cudeck, 1993). 


\subsubsection{Adjustment of the global model}

For the adjustment of the global model, three sets of indexes were analyzed: absolute, incremental and parsimony indexes. The results are presented in tabular form for comparison purposes. We started testing the structure of the two models. We tested the model provided by the first exploratory factorial analysis consisting of two dimensions and eleven items (model 1 - AFE 1). We also tested the same two-dimensional model (and one less item) corresponding to the results provided by the exploratory factor analysis on the second data collection (model 2 - AFE 2). We decided to integrate a dimension not proposed by exploratory factor analysis, for several reasons. First, the two-dimensional structure resulting from the exploratory factor analysis was not confirmed by the confirmatory factor analysis. Insufficient results in terms of adjusting the global model led us to specify these models again. Next, this two-dimensional structure does not correspond to the vision of the literature, especially the one that is similar to the BSC, which proposes four dimensions. Also, this two-dimensional structure, which encompasses customer satisfaction and productivity in the same dimension, does not correspond to what we discovered during the interviews or to the results of the qualitative analyses produced by the Alceste software. In this case, the literature (for example Evrard, et al., 2009) suggests that we should not "blindly" follow the statistical results, but rather that we get a little out of them. This is what we have done, integrating one dimension, that is, dividing the first dimension proposed by the factorial analysis (one dimension relating to satisfaction and one to productivity) into two. Content validity is more important than other validities. This led us to propose a third dimension. We therefore continued the comparison with a three-dimensional model and eleven items (model 3). We also tested a model 4 composed of three dimensions and ten items (Idec). In Model 4, we chose to remove the item with the lowest factor contribution (Idec: 0.553), close to the lower limit (0.5).

Table 6: Summary of the indexes of the model Net Impacts adjustment, 4 models tested

\begin{tabular}{|c|c|c|c|c|}
\hline $\begin{array}{l}\text { Summary of the indexes of } \\
\text { adjustment }\end{array}$ & $\begin{array}{l}\text { Model } 1 \\
2 \text { dimensions, } 11 \\
\text { items, AFE } 1\end{array}$ & $\begin{array}{l}\text { Model } 2 \\
2 \text { dimensions, } 10 \\
\text { items, AFE } 2\end{array}$ & $\begin{array}{l}\text { Model } 3 \\
3 \text { dimensions, } 11 \\
\text { items }\end{array}$ & $\begin{array}{l}\text { Model } 4 \\
3 \text { dimensions, } 10 \\
\text { items (except } \\
\text { Idec) }\end{array}$ \\
\hline $\begin{array}{l}\text { Absolute measurement indexes } \\
\text { - Chi-square/dl }(<2) \\
\text { - GFI and AGFI } \\
\text { - Gamma1 and Gamma2 }(>0,9) \\
\text { - RMSEA }(<0,10)\end{array}$ & $\begin{array}{l}3,06 \\
0,887 / 0,886 \\
0,92 / 0,877 \\
0,105\end{array}$ & $\begin{array}{l}3,6 \\
0,881 / 0,807 \\
0,901 / 0,853 \\
0,121\end{array}$ & $\begin{array}{l}2,6 \\
0,910 / 0,854 \\
0,943 / 0,908 \\
0,09\end{array}$ & $\begin{array}{l}2,3 \\
0,933 / 0,885 \\
0,963 / 0,937 \\
0,077\end{array}$ \\
\hline $\begin{array}{l}\text { Incremental adjustment indexes } \\
\text { - NFI and CFI }(>0,9) \\
\text { - Non-standardized index Bentler } \\
\text { and Bonnet }(>0,9)\end{array}$ & $\begin{array}{l}0,869 / 0,906 \\
0,880\end{array}$ & $\begin{array}{l}0,861 / 0,893 \\
0,859\end{array}$ & $\begin{array}{l}0,891 / 0,928 \\
0,903\end{array}$ & $\begin{array}{l}0,916 / 0,949 \\
0,928\end{array}$ \\
\hline $\begin{array}{l}\text { Parsimony indexes } \\
\text { - PNFI (highest value) } \\
\text { - AIC (lowest value) }\end{array}$ & $\begin{array}{l}0,679 \\
0,934\end{array}$ & $\begin{array}{l}0,66 \\
0,878\end{array}$ & $\begin{array}{l}0,664 \\
0,836\end{array}$ & $\begin{array}{l}0,651 \\
0,634\end{array}$ \\
\hline
\end{tabular}

Model No. 4, composed of three dimensions and ten items, presents the best fit of the global model. Chisquare is significant at a probability level of less than $1 \%$. The GFI is 0.933 which is above the acceptance threshold. Thus, the probability that the theoretical model will adjust correctly to the empirical data is verified. All incremental indices are greater than 0.9. This suggests that these indices support the acceptance of the theoretical model. Finally, regarding parsimonious adjustment measures, the AIC and PNFI indices are acceptable.

The three dimensions are:

Dimension 1: productivity, 5 items (time saving, work simplification, quality of life at work, quality of work, organization)

Dimension 2: Customer satisfaction, 3 items (satisfaction, customer service, image)

Dimension 3: control, 2 items (operational risk, settlement).

\subsubsection{Adjusting the measurement model}

The adjustment of the measurement model for this factor structure should now be analyzed. It is necessary to check the fit of each construct with its indicators. The first step will be a statistical review of the factor contributions of the indicators. Student's T-test must be greater than 1.96 at the $5 \%$ significance level for each 
factor contribution. The following table 7, presenting the estimates of the parameters, indicates that each ttest is well above 1.96, verifying the link from each indicator to its construct. In a second step, we evaluate the reliability of internal consistency and the variance explained. Jöreskog's rhô, a coefficient of the reliability of internal consistency, is based on a measure of the factor contributions of items. One of the advantages of this indicator is that it is insensitive to the number of items. Above the 0.70 threshold, the reliability of the construction is considered good, which is the case.

Table 7: Summary of criteria for adjustment of the measurement model, Net Impacts

\begin{tabular}{|l|l|}
\hline Adjustment criteria & Model 4; $\mathbf{3}$ dimensions, 10 items \\
\hline $\begin{array}{l}\text { Validity of the construct } \\
\text { factorial weight }(\geq 0,5) \text { and Test } t\end{array}$ & $0,74(t=19,9)$ \\
$(>1,96)$ & $0,75(t=18,4)$ \\
& $0,76(t=19,1)$ \\
& $0,68(t=18,9)$ \\
& $0,70(t=17)$ \\
& $0,78(t=22,8)$ \\
& $0,83(t=28,6)$ \\
& $0,66(t=14,5)$ \\
& $0,65(t=10,1)$ \\
& $0,86(t=12,8)$ \\
\hline Reliability & $\mathrm{D} 1: 0,80$ \\
Coefficient of internal consistency & $\mathrm{D} 2: 0,85$ \\
(Jöreskog's $\rho>0,6)$ & $\mathrm{D} 3: 0,73$ \\
\hline Convergent validity $>0,50$ & $\mathrm{D} 1: 0,58$ \\
& $\mathrm{D} 2: 0,54$ \\
\hline Discriminant validity & $\mathrm{D} 3: 0,58$ \\
\hline & $\mathrm{D} 1: 0,58>(0,586)^{2}$ Yes \\
& $\mathrm{D} 2: 0,54>(0,477)^{2}$ Yes \\
& $\mathrm{D} 3: 0,58<(0,812)^{2}$ No \\
\hline
\end{tabular}

Dimension three (D3) has a slightly weak discriminating validity, but we decide to retain this dimension for its conceptual importance. The results of the confirmatory step allow us to validate the hypothesis that Net Impacts is a multidimensional construct with three dimensions. Thus, the finalized conceptual model of Net Impacts is summarized in Figure 3 below.

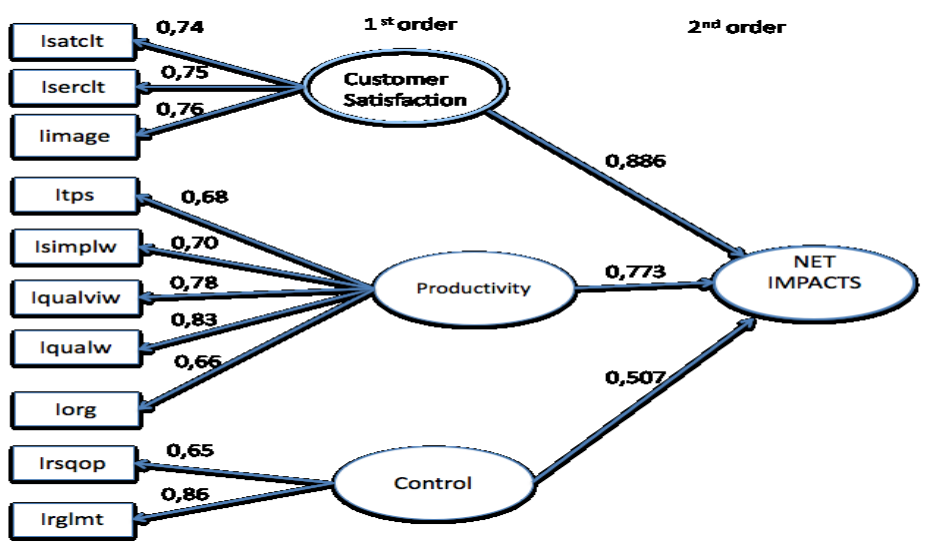

Figure 3: Final Conceptual Model of Net Impacts

\subsection{Results}

The first result concerns the construct itself and the percentages of answers obtained through our questionnaire. The second important result relates to socio-demographic variables. We proposed and validated an instrument, inspired by the BSC and following the Churchill paradigm, which measures the Net Impacts perceived by account officers using the front office banking IS. This tool consists of three categories, relating to customer satisfaction ( 3 items), productivity (5 items) and risk ( 2 items). 


\subsection{The influence of socio-demographic variables}

To test the links between the socio-demographic variables of the model and the variable Net Impacts, we carried out ANOVAs. Indeed, the analysis of variance allows us to examine and interpret differences in averages observed between several groups for the same variable. ANOVAs are used to treat differences in means of a quantitative dependent variable when the independent variable has more than two modalities. The analysis of variance is therefore used to test the null hypothesis of equal averages. To evaluate the results of variance analyses, the F-test using a Fisher-Snedecor law is used. The Levene test is used to test this null hypothesis that variances are equal in the groups. We try to accept this hypothesis, i.e., to obtain significance greater than $5 \%$.

The ANOVA results show that only the occupied function influences the variable Net Impacts. To carry out this test, we grouped the functions of account officers to distinguish them from those of branch manager (see Appendix C). The results show that, on average, managers have a better appreciation of their IS.

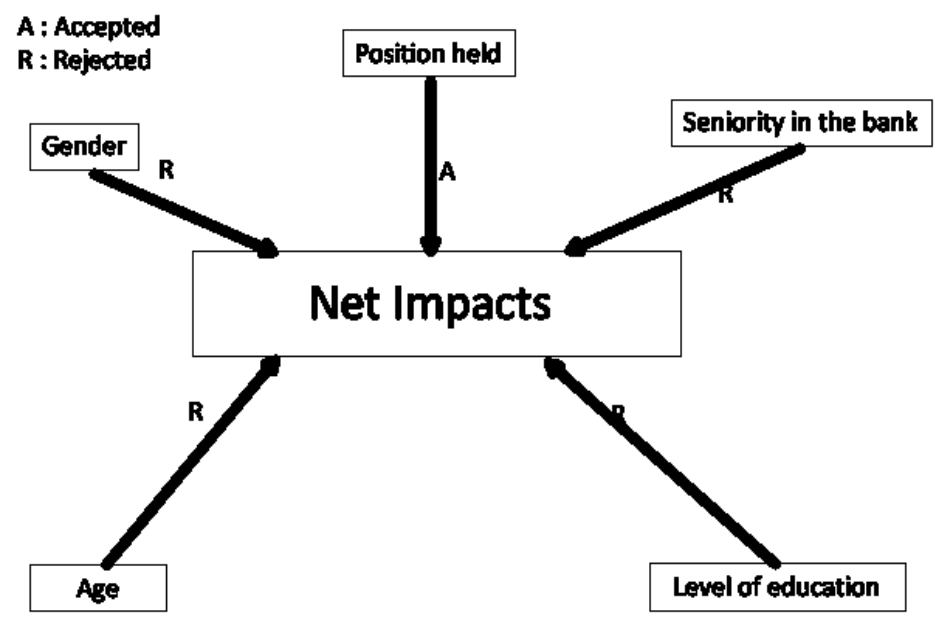

Figure 4: Influence of socio-demographic characteristics on the variable Net Impacts

\section{Discussion and implications}

The review of the literature pointed out that the variable Net Impacts, a key variable in the models for IS evaluation, was rarely operationalized according to a rigorous method and never for the banking sector. We then proposed a construct, namely Net Impacts, contextualized in the banking field, applying the steps of the Churchill paradigm for a more rigorous construction of our scale of measurement. Qualitative studies based on semi-directive interviews, the results of which were compared with the literature, enabled us to generate a sample of items. We then started a quantitative phase to test the validity and reliability of this instrument, with exploratory but also confirmatory factorial analyses. The data collection was carried out by means of two questionnaires put on line consecutively in two large banks, targeting account officers. This instrument consists of three categories: a dimension relating to the perception of productivity gains ( 5 items); a dimension linked to the improvement of customer satisfaction (3 items); and a dimension linked to the improvement of risk control ( 2 items). Reliable and valid, this instrument can be used in a very concrete way to measure and improve the perception of Net Impacts among banking executives. Three main theoretical contributions can be highlighted.

The first is to respond both to a lack of literature and a demand for it, namely operationalizing the key constructs of IS evaluation models with particular attention to context (DeLone and McLean, 2003, 2016). Our research enables us to accurately measure the Net Impacts of front-office IS in the banking sector. In addition, the literature, including Petter, DeLone and McLean (2013) using the DeLone and McLean (1992, 2003) models, underlines the lack of comprehensive and integrative research on variables influencing IS success. Our research is part of this objective to consolidate the literature on independent variables affecting the success of IS. By showing that in the banking field only the function occupied by the user influences the perception of the impact of IS, we contribute to a better knowledge of the variables related to the evaluation of IS. 
The second theoretical contribution is that our construct encompasses broad and complex concepts related to the user and his work. Alter (2008) argues that it is by taking into account a broad framework in which IS is incorporated that IS impact can be truly assessed. Our three-dimensional construction (customer satisfaction, productivity, control) shows how the information system supports the user in a wide spectrum of work. Indeed, our concept encompasses concepts such as the image conveyed to consumers through IS, working time, or compliance with the regulations by IS. They are diverse, broad notions which are contained in our construct through the different dimensions. Indeed, we note that of the four initial categories proposed, only the one relating to learning/adaptation has disappeared. This can be explained by the lack of time and above all by the competitive pressure imposed on account officers (Michel and Cocula, 2014a). Although IS allows learning to take place in practice, is not used as such and is not perceived as being able to bring this benefit, due to the lack of time to devote to this learning activity. This brings us directly to the three dimensions highlighted. It appears that for account officers, the net perceived impacts of their IS are strongly linked to the productivity dimension. IS is a tool that should be used to increase productivity by saving time, simplifying work, improving organization, improving work quality and even the quality of life at work. It is important to note that this productivity dimension is both quantitative (time saving) and qualitative, in the sense that the quality of work performed and the quality of life at work seem to be affected (Retour, Dubois and BobillierChaumon, 2006). In addition, while exploratory factor analyses led us to group together productivity and customer satisfaction, confirmatory factor analyses clearly distinguish between these two dimensions. Finally, the last dimension highlighted, control, appears to be specific to the banking sector. The two items (operational and regulatory risks) are closely linked to the front office banking business. As banking activity is closely linked to risks, it is interesting to note that for account officers, IS is a risk control tool and that far from being perceived as a constraint, it is seen as a benefit.

The third contribution relates to the current emphasis on customers. IS evaluation has long revolved around three main actors: developer, user and manager. In their synthesis of the literature on IS evaluation, DeLone and McLean (2016) urge us to add other players, such as consumers, but also employees, suppliers, the State, and to position ourselves in the era of the consumer (customer-focused area). Our construct responds to this twofold expectation of the literature. The "employee" user is the main evaluator, and one of the dimensions considered by this user is customer satisfaction. Thus, by adapting our structure to the complexity of the account officers' work and incorporating customer satisfaction, we have met the expectations of the literature in the specific field of banking. Another remarkable point is related to the second dimension of our construct, customer satisfaction. The impacts perceived by account officers are related to customer relations and customer satisfaction. IS is therefore a tool that they also consider "customer-oriented". This confirms the change that has taken place in banks over the last few years: very product-focused in the past, account officers are now oriented towards "customer satisfaction" (des Garets et al., 2009).

From a managerial point of view, Jones and Beatty (2001), but also Rosemann and Vessey (2008) have shown that the main variables of DeLone and McLean's IS success models are very little used in managerial practice. Managers are more likely to evaluate the process of developing IS (budget, time frame, different phases) with a cost-benefit orientation. One of the reasons given by the literature for this failure to take key evaluation variables into account in practice is the absence of a simple and valid proposal for tools. Similarly, Petter, DeLone and McLean (2012) show that there is a considerable mismatch between theory and practice in IS evaluation. Managers do not often have the tools to assess the user's perspective on the impacts of using their IT system. Thus, this instrument represents a strategic tool for monitoring and guiding efforts to increase performance. This tool should enable managers to understand the positive and negative impacts of IT on the most important factors in the banking sector. Our tool meets both a need of the literature and an expectation of managers. DeLone and McLean (2016) point to the need for operationalized tools that guide managers and CIOs in allocating IT investments.

For example, there are many lessons to be learned from the percentages of favourable opinions of account officers (Appendix B). If we try to measure general Net Impacts (average of all frequencies per item), we obtain a score of $53.17 \%$. This means that just over one in two account officers subscribe to the general impression that their IS generates positive impacts. This is very low, especially in view of the expectations of the management bodies and the colossal investment in IS and the mandatory use of the IS in the banking sector. Let's now break down the results by dimension. With regard to the first dimension, only $49.18 \%$ of respondents believe that the IS improves their productivity (in a general sense). One in two respondents does not perceive a simplification of work by the IS. Worse still, only $43.8 \%$ of respondents believe that the IS 
improves the quality of work life (56.2\% disagree or have no opinion). The IS is therefore not seen as a tool that provides comfort at work. This may result in a barrier to its use. This is a fundamental point on which branch managers and managers should reflect in order to find solutions to remedy it.

With regard to the second dimension, we find these very low rates of positive perception about improving customer satisfaction. On average, only $46 \%$ of account officers perceive a general improvement in customer satisfaction through the IS. The item questioning the perception of improved customer satisfaction, but also the one concerning the image, obtained particularly low rates $(41.7 \%)$. These are the lowest scores of the entire questionnaire and they concern one of the most important dimensions for banks, especially today when an account officer is subject to significant competitive pressure, when he is "objective in the short term" and when he has to adapt to new customer purchasing behaviour. The margin of progress again is significant. These low scores must be taken into account when taking corrective actions.

On the other hand, with regard to the third dimension, that of improving risk control through the IS, a high percentage of favourable opinions (76.6\%) should be noted. It is interesting to note that the IS is perceived above all as a "safeguard" and not only as a regulatory constraint.

This table should alert CIOs, but also business managers. It is important to remedy such a perception of the net benefits related to the IS. This tool, which is not difficult to implement, can be used as a benchmark over time to measure the improvement in the perception of net benefits. These measures will thus make it possible to implement corrective actions.

\section{Conclusion, limitations and future research}

Organizations need to be aware of Net Impacts about their information systems. Net Impacts are a key determinant of information system evaluation. This paper has focused on developing an evaluation construct for Net Impacts in the banking sector.

This study proposes, develops and tests a construct for assessing the Net Impacts of front office information systems on account officers. We propose a three-dimensional construct (customer satisfaction, productivity, control), which shows how the information system supports the user.

In terms of theoretical implications, the present research provides a greater understanding of Net Impacts. This result is important: it stresses the indispensable need for IS evaluation models to be contextualized in terms of their environment. The construct must be studied in context. In the banking sector, for front office IS, it appears that the three-dimensional construct (customer satisfaction, productivity, control) is the most important to evaluate Net Impacts. In addition, the literature, including Petter, DeLone and McLean (2013) using the DeLone and McLean $(1992,2003)$ models, points to the lack of comprehensive and integrative research on variables influencing IS success. In this way, our research shows that only the occupied function influences the variable Net Impacts.

Moreover, from the managerial point of view, the findings of this study significantly demonstrate the ability of three mains dimensions (customer satisfaction, productivity, and control) to influence IS success. Practitioners should assign great importance to these dimensions of Net Impacts. This questionnaire constitutes a tool for improving IS Net Impacts. These results show CIOs the particular criteria they must focus on in order to get a better perception of Net Impacts. This research proposes a useful evaluation instrument. Similarly, this instrument could be used by IS developers. They could include some of its characteristics in their specifications.

IS impacts must be measured at several stages over time. A longitudinal study should be considered. This would allow for the study of changes in user perception. A further limitation is that the study was conducted on a national level. Also, in this study, we did not study the feedback between Net Impacts and other variables in the DeLone and McLean (2016) model, such as satisfaction or use. In addition, a research approach aimed at improving the external validity of this work would be to duplicate this study towards new sectors of activity close to the bank. We are thinking in particular of the insurance sector, because it is very close to the banking sector in its activities and the importance of information. Finally, it would also be appropriate to test this model in sectors with high informational intensity (Porter and Millar, 1985) whose profession differs from that 
of banking or insurance. This is the case, for example, in the business services sector, particularly in the areas of auditing, accounting or legal services, which are recognized as highly informational. Finally, in future research, the human resource implications of this instrument should be further explored.

\section{References}

Acheampong, O. and Moyaid, S. A., 2016. An integrated model for determining business intelligence systems adoption and post-adoption benefits in banking sector. Journal of Administrative and Business Studies, 2(2), p. 84-100.

Ahmad, M.I., 2014. Incorporating Technology Acceptance into Composite IT BSC for IT Investment Evaluation. Proceedings of INFOS2014.

Alshardan, A., Goodwin, R. and Rampersad, G., 2016. A Benefits Assessment Model of Information Systems for Small Organizations in Developing Countries. Computer and Information Science, 9(1), p. 1-20.

Alter, S., 2008. Defining information systems as work systems: implications for the IS field. European Journal of Information Systems. 17 (5), p. 448-469.

Amoako-Gyampah, K. and Salam, A. F., 2004. An extension of the technology acceptance model in an ERP implementation environment. Information and management, 41(6), p. 731-745.

Andriessen, J.E., 2012. Working with groupware: Understanding and evaluating collaboration technology. Springer Science and Business Media.

$\mathrm{Au}$, N., Ngai, E. W. and Cheng, T. E., 2002. A critical review of end-user information system satisfaction research and a new research framework. Omega, 30(6) p. 451-478.

Ballantine, J., Bonner, M., Levy, M., Martin, A., Munro I. and Powell P L., 1998. Developing a 3-D Model of Information Systems Success. In Information Systems Success Measurement. Ed. Garrity E., Sanders G L. Hershey, USA: Idea Group Publishing, p. 46-59.

Baker, C.R., Cohanier, B. and Leo, N.J., (2017). Breakdowns in internal controls in bank trading information systems: The case of the fraud at Société Générale. International Journal of Accounting Information Systems, 26, p. 20-31.

Bentler, P.M. and Bonett, D.G., 1980. Significance Tests and Goodness of Fit in the Analysis of Covariance Structures. Psychological Bulletin, 88(3) p. 588-606.

Bèzes, C., 2014. Definition and Psychometric Validation of a Measurement Index Common to Website and Store Image. Journal of Business Research, 67(12) p. 2559-2578.

Borena, B. and Negash, S., (2016). IT infrastructure role in the success of a banking system: The case of limited broadband access. Information Technology for Development, 22(2), p. 265-278.

Bhatt, G. D., Wang, Z. and Rodger, J. A., 2017. Information Systems Capabilities and Their Effects on Competitive Advantages: A Study of Chinese Companies. Information Resources Management Journal, 30(3), p. 41-57.

Bradley, R.V., Pridmore, J.L. and Byrd T.A., 2006. Information Systems Success in the Context of Different Corporate Cultural Types: an Empirical Investigation. Journal of Management Information Systems, 23(2) p. 267-294.

Bravo, E. R., Santana, M. and Rodon, J., 2015. Information systems and performance: the role of technology, the task and the individual. Behaviour and Information Technology, 34(3), p. 247-260.

Brown, M.W. and Cudeck, R., 1993. Alternative ways of assessing model fit Testing structural equation models. Thousand Oaks, CA: Sage Publications, p. 136-162.

Brynjolfsson, E. and Hitt, L.M. 1996. Paradox Lost? Firm-level Evidence on the Returns to Information Systems Spending, Management Science, 42(4), p. 541-558.

Bui, Q.N., Hansen, S., Liu, M. and Tu, Q.J., 2018. The productivity paradox in health information technology. Communications of the ACM, 61(10), p. 78-85.

Chand, D., Hachey, G., Hunton, J., Owhoso, V., and Vasudevan, S., 2005. A Balanced Scorecard Based Framework for Assessing the Strategic Impacts of ERP Systems. Computers in industry, 56(6), p. 558-572.

Chang, J.C.J. and King, W.R., 2005. Measuring the Performance of Information Systems: A Functional Scorecard. Journal of Management Information, 22(1), p. 85-115.

Chen, Y., Wang, Y., Nevo, S., Benitez-Amado, J. and Kou, G., 2015. IT capabilities and product innovation performance: The roles of corporate entrepreneurship and competitive intensity. Information and Management, 52(6), p. 643-657.

Chin, W.W. and Lee, M.K.O., 2000. On the formation of end user computing satisfaction: a proposed model and measurement instrument. 21st International Conference on Information Systems, Brisbane, Australia, p. 553-563.

Churchill, G.A., 1979. A Paradigm for Developing Better Measures of Marketing Constructs. Journal of Marketing Research, 16(1), p. 64-73.

DeLone, W.H. and McLean, E.R., 1992. Information Systems Success: The Quest for the Dependent Variable. Information Systems Research, 3(1) p. 60-95.

DeLone, W.H. and McLean, E.R., 2003. The DeLone and McLean Model of Information Systems Success: a Ten-Year Update. Journal of Management Information Systems, 19(4), p. 9-30.

DeLone, W.H. and McLean, E.R. 2004. Measuring e-commerce success: Applying the DeLone and McLean information systems success model. International Journal of electronic commerce, 9(1), p. 31-47.

DeLone, W.H. and McLean, E.R., 2016. Information Systems Success Measurement. Foundations and Trends in Information Systems, 2(1), p. 1-116.

Des Garets, V., Paquerot, M. and Sueur, I., 2009. L'approche relationnelle dans les banques, mythes ou réa lité ? Revue Française de Gestion, 191, p. 123-138. 
Doll W.J., Koufteros X. and Torkzadeh G., 2005. Confirmatory Factor Analysis and Factorial Invariance of the Impact of Information Technology Instrument. Omega, 33(2), p. 107-118.

Drnevich, P. L. and Croson, D. C. 2013. Information technology and business-level strategy: toward an integrated theoretical perspective. MIS Quarterly, p. 483-509.

Ebrahimi, M., Hassanzadeh, A., Elahi, S. and Ebrahimi, M., 2013. The Relationship Between Information Systems Strategic Management Based on Balanced Scorecard and Information Systems Performance. International Journal of Business Administration, 4 (4), p. 35.

Ein-Dor, P. and Segev, E., 1978. Organizational Context and the Success of Management Information Systems, Management Science, 24(10), p. 1064-1077.

Epstein, M. J. and Rejc, A., 2005. How to Measure and Improve the Value of IT. Strategic Finance, 87(4), p. 34.

Evrard, Y., Pras, B., Roux, E., Desmet, P., Dussaix, A.M. and Lilien, G. L., 2009. Market-Fondements et méthodes des recherches en marketing, Paris, Dunod, 3 éd.

Fang, M. and Lin, F., 2006. Measuring the Performance of ERP System from The Balanced Scorecard Perspective. Journal of American Academy of Business, 10(1), p. 256-263.

Finn, A. and Wang, L., 2014. Formative vs. Reflective Leasures: Facets of Variation, Journal of Business Research. 67(1), p. 2821-2826.

Gable, G. G., Sedera, D. and Chan, T., 2008. Re-conceptualizing information system success: The IS-impact measurement model. Journal of the association for information systems, 9(7), p. 18.

Goodhue, D.L. and Thompson, R.L., 1995. Task-technology fit and individual performance. MIS Quarterly, 19(2), p. 213-236.

Grover, V. and Davenport T.H., 2001. General perspectives on knowledge management: Fostering a research agenda. Journal of Management Information Systems. 18(1), p. 5-21.

Henderson, J. C. and Venkatraman, H. 1999. Strategic alignment: Leveraging information technology for transforming organizations. IBM systems journal, 38(2.3), p. 472-484.

Hou, C.K., 2016. Using the balanced scorecard in assessing the impact of Bl system usage on organizational performance: An empirical study of Taiwan's semiconductor industry. Information Development, 32(5), p. 1545-1569.

Hsu, J.S.C., Shih, S.P., Chiang, J.C. and Liu, J.Y. C. 2012. The impact of transactive memory systems on IS development teams' coordination, communication, and performance. International Journal of Project Management, 30(3), p. 329340.

Ives, B. and Learmonth, G. 1984. The Information System as a Competitive Weapon, Communications of the ACM, 27(12), p. 1193-1201.

Jones, M. C. and Beatty, R. C., 2002. User satisfaction with EDI: an empirical investigation. In Advanced Topics. Information Resources Management, 1 p. 204-222.

Jöreskog, K.G., 1971. Statistical Analyses of Sets of Congeneric Tests. Psychometrika, 36, p. 109-133.

Kaplan, R. and Norton, D., 1992. The Balanced Scorecard: Measures that Drive Performance. Harvard Business Review, 70(1) p. 71-79.

Kim, J., Suh E. and Hwang H., 2003. A model for evaluating the effectiveness of CRM using the Balanced Scorecard. Journal of interactive Marketing, 17 (2), p. 5-19.

Laumer, S., Maier, C. and Weitzel, T., 2017. Information quality, user satisfaction, and the manifestation of workarounds: a qualitative and quantitative study of enterprise content management system users. European Journal of Information Systems, 26(4), p. 333-360.

Lawson-Body, A., Willoughby, L., Lawson-Body, L. and Logossah, K., 2017. Developing and validating a cultural user satisfaction instrument in developing Countries. Journal of Computer Information Systems, 57(4), p. 319-329.

Lee, A. H., Chen, W. C. and Chang, C. J., 2008. A fuzzy AHP and BSC approach for evaluating performance of IT department in the manufacturing industry in Taiwan. Expert systems with applications, 34(1), p. 96-107.

Lee, N. and Hooley, G., 2005. The Evolution of 'Classical Mythology' Within Marketing Measure Development. European Journal of Marketing, 39 (3/4), p. 365-385.

Lee, S., Park, S.B. and Lim, G.G., 2013. Using Balanced Scorecards for the Evaluation of Software-as-a-Service. Information and Management, 50(7), p. 553-561.

Lucas, H.C. Jr., 1975. Performance and the Use of Information System. Management Science, 21(8), p. 908-919.

Mackenzie, S., 2003. The Danger of Poor Construct Conceptualization. Journal of the Academy of Marketing Science, 31(3), p. 323-326.

MacKenzie, S., Podsakoff, P. and Podsakoff, N., 2011. Construct Measurement and Validation Procedures in MIS and Behavioral Research: Integrating New and Existing Techniques. MIS Quarterly, 35 (2) p. 293-334.

Mahmood, M. A., Burn, J. M., Gemoets, L. A., and Jacquez, C., 2000. Variables affecting information technology end-user satisfaction: a meta-analysis of the empirical literature. International Journal of Human-Computer Studies, 52(4), p. 751-771.

Markus, M.L and Soh, C., 1993. P. Banking on Information Technology : Converting IT Spending into firm Performance, in Strategic Information Technology Management, Banker R.D., Kauffman R.J. and Mahmood M. (Eds.), Idea Group Publishing, Harrisburg, p. 375-403.

Martinsons, M. and Davison, R., 1999. The Balanced Scorecard: a Foundation for the Strategic Management of Information Systems. Decision Support Systems, 25(1), p. 71-87.

Michel, S. and Cocula, F., 2014a. Adaptation au domaine bancaire du modèle d'évaluation du succès des systèmes d'information ISSM de DeLone et McLean. Système d'Information Management, 19(1), p. 7-49. 
Michel, S. and Cocula, F., 2014b. Relations entre les variables de qualités du système d'information dans les secteurs à haute intensité informationnelle : le cas du SI de front office du secteur bancaire français ". 18ème colloque de l'AIM, Aix en Provence.

Michel, S. and Cocula, F., 2014c. L'évaluation des systèmes d'information : un état de l'art. Revue Management and Avenir, 74, p. 33-51.

Milis, K. and Mercken, R., 2004. The Use of the Balanced Scorecard for the Evaluation of Information and Communication Technology Projects. International Journal of Project Management, 22, p. 87-97.

Mirani, R. and Lederer, A., 1998. An Instrument for Assessing the Organizational Benefits of IS Projects. Decision Sciences, 29(4), p. 803-838.

Motwani, B. and Sharma, R. K., 2016. A Study on the Effect of Enterprise Resource Planning (ERP) on People of an Organization. Journal of Technology Management for Growing Economies, 7(1), p. 73-84.

Murphy, K.E. and Simon, S.J., 2002. Intangible benefits valuation in ERP projects. Information Systems Journal, 12 (4), p. 301-320.

Padinha, B. and O'Neill, H., 2016. Information systems design and User Satisfaction: A banking case study. Atas da Conferência da Associação Portuguesa de Sistemas de Informação, 15 (5), p. 17-35.

Parsons, G.L. 1983. Information Technology: a New Weapon. Sloan Management Review, 25(1), p. 3-13.

Pashkevich, N. and Haftor, D., 2014. IT-driven productivity at the individual level: Complementarities matter. In The 8th European Conference on IS Management and Evaluation, University of Ghent, Belgium, p. 380-383.

Petter, S., DeLone, W.H. and McLean, E.R., 2012. The past, present, and the future of IS Success. Journal of the Association for Information Systems, 13(5), p. 341-362.

Petter, S., DeLone, W.H. and McLean, E.R., 2013. Information Systems Success: The Quest for the Independent Variables. Journal of Management Information Systems, 29(4), p. 7-62.

Porter, M.E. and Millar, V., 1985. How Information Gives You Competitive Advantage. Harvard Business Review, 63(4), p.149-160.

Retour, D., Dubois, M. and Bobillier-Chaumon, M.E., 2006. Les professionnels de la banque le cas des chargés de clientèle bancaire. Revue Française de Gestion, (168/169), p. 205-220.

Rosemann, M. and Vessey, I., 2008. Toward improving the relevance of information systems research to practice: the role of applicability checks. MIS Quarterly, 32(1), p. 1-22.

Rosemann, M. and Wieses, J., 1999. Measuring the Performance of ERP Software-a Balanced Scorecard Approach. AMR Research.

Salzberger, T. and Koller, M., 2013. Towards a New Paradigm of Measurement in Marketing. Journal of Business Research, 66(9), p. 1307-1317.

Scott, M., DeLone, W.H., Golden, W. and McLean, E.R., 2015. IS success 2.0: an extension and redefinition of the DeLone and McLean IS Success Model. Working paper.

Sedera, D., Eden, R. and McLean, E., 2013. Are we there yet? A step closer to theorizing information systems success. Thirty Fourth International Conference on Information Systems, Milan 2013.

Sedera, D., Gable, G., and Chan, T., 2004. Measuring enterprise systems success: The importance of a multiple stakeholder perspective. ECIS 2004 Proceedings, 100.

Sethi, V. and King, W.R., 1994. Development of Measures to Assess the Extent to Which an Information Technology Application Provides Competitive Advantage, Management Science, 40(12) , p. 1601-1627.

Shao, Z., 2019. Interaction effect of strategic leadership behaviors and organizational culture on IS-Business strategic alignment and Enterprise Systems assimilation. International Journal of Information Management, 44, p. 96-108.

Strassman, P.A., 1997. Computers Have Yet to Make Companies More Productive, Computersword, 31 (37), p. 92-92.

Summers, J.O., 2001. Guidelines for Conducting Research and Publishing in Marketing: from Conceptualization through the Review Process. Journal of the Academy of Marketing, American Marketing Association, 29(4), p. 405-415.

Sun, J. and Teng, J.T. 2017. The construct of information systems use benefits: Theoretical explication of its underlying dimensions and the development of a measurement scale. International Journal of Information Management, 37(5), p. 400-416.

Torkzadeh, G. and Doll, W.J., 1999. The Development of a Tool for Measuring the Perceived Impact of Information Technology on Work. Omega - The International Journal of Management Science, 27(3), p. 327-339.

Turner, J., 1985. Organizational Performance, Size and the Use of Data Processing Ressources, Working paper (58), Center for Research in Information System, New York University.

UI-Ain, N., Vaia, G. and DeLone, W.H., 2019, January. Business intelligence system adoption, utilization and success-A systematic literature review. In Proceedings of the 52nd Hawaii International Conference on System Sciences.

Vaezi, R., Mills, A., Chin, W. and Zafar, H., 2016. User Satisfaction Research in Information Systems: Historical Roots and Approaches. Communications of the Association for Information Systems, 38(27), p. 501-532.

Van Grembergen, W.R., Saull, R. and. De Haes S., 2003. Linking the IT Balanced Scorecard to the Business Objectives at a Major Canadian Financial Group. Journal of Information Technology Cases and Applications, 5(1), p. 23-50.

$\mathrm{Wu}$, L. and Chen, J.L., 2014. A stage-based diffusion of IT innovation and the BSC performance impact: A moderator of technology-organization-environment. Technological Forecasting and Social Change, 88, p. 76-90. 


\section{Appendix A}

Sample frame, Bank $X$, first data collection

\begin{tabular}{|l|l|l|}
\hline Profession & Number & percentage \\
\hline Reception & 113 & 19,8 \\
\hline $\begin{array}{l}\text { Account officer for private } \\
\text { customers }\end{array}$ & 190 & 33,3 \\
\hline $\begin{array}{l}\text { Account officer for professional } \\
\text { customers }\end{array}$ & 133 & 23,3 \\
\hline $\begin{array}{l}\text { Account officer for wealth } \\
\text { management }\end{array}$ & 34 & 5,9 \\
\hline Agency Manager & 101 & 17,7 \\
\hline TOTAL & $\mathbf{5 7 1}$ & $\mathbf{1 0 0}$ \\
\hline
\end{tabular}

Sample frame, Bank $\mathrm{Y}$, second data collection

\begin{tabular}{|l|l|l|}
\hline Profession & Number & percentage \\
\hline Account officer & 183 & 33,3 \\
\hline $\begin{array}{l}\text { Account officer (for private or professionals } \\
\text { individuals) }\end{array}$ & 220 & 40 \\
\hline Account officer for wealth management & 20 & 3,63 \\
\hline Agency Manager and head of branch & 127 & 23,1 \\
\hline TOTAL & $\mathbf{5 5 0}$ & $\mathbf{1 0 0}$ \\
\hline
\end{tabular}

Appendix B: Results of Anova for the variable "position held"

Average of variables of the SI success model by position held

\begin{tabular}{|l|l|l|}
\hline POSITION HELD & Net Impacts \\
\hline \multirow{3}{*}{ Turnover } & Mean Average & 3,1965 \\
\cline { 2 - 3 } & $\mathrm{N}$ & 142 \\
\cline { 2 - 3 } & standard deviation &, 64845 \\
\hline \multirow{3}{*}{$\begin{array}{l}\text { Head of the } \\
\text { branch }\end{array}$} & Mean Average & 3,5540 \\
\cline { 2 - 3 } & $\mathrm{N}$ & 50 \\
\cline { 2 - 3 } & standard deviation &, 57613 \\
\hline \multirow{3}{*}{ Total } & Mean Average & 3,2896 \\
\cline { 2 - 3 } & $\mathrm{N}$ & 192 \\
\cline { 2 - 3 } & standard deviation &, 64831 \\
\hline
\end{tabular}

One-way ANOVA Analysis: Position held on Net Impacts

\begin{tabular}{|l|l|l|l|l|l|}
\hline \multicolumn{2}{|l|l|l|}{} & \multicolumn{2}{l|}{ Levene's Test } & \multicolumn{2}{l|}{ ANOVA } \\
\hline \multicolumn{2}{|l|}{ One-way ANOVA Position held / Net Impacts } & F & p. & F & P \\
\hline POSITION HELD & NET IMPACTS & 3,099 & $\mathbf{0 , 0 8 0}$ & 11,887 & $\mathbf{0 , 0 0 1}$ \\
\hline
\end{tabular}


The Electronic Journal of Information Systems Evaluation Volume 22 Issue 22019

\section{Appendix C: Percentage of positive opinions about Net Impacts}

\begin{tabular}{|c|c|c|c|}
\hline \multicolumn{2}{|c|}{ Items and dimensions representing Net Impacts } & \multirow{2}{*}{$\begin{array}{l}\text { Percentage of positive } \\
\text { responses }(\mathrm{N}=192) \\
449,5\end{array}$} & \multirow{2}{*}{$\begin{array}{c}\text { Percentage of positive } \\
\text { responses }(N=192) \\
49,18\end{array}$} \\
\hline Productivity & Time saving & & \\
\hline & Work simplification & 50,5 & \\
\hline & Quality of life at work & 43,8 & \\
\hline & Quality of work & 54,7 & \\
\hline & Organization & 47,4 & \\
\hline \multirow[t]{3}{*}{ Customer satisfaction } & Satisfaction & 41,1 & 46 \\
\hline & Customer client & 55,2 & \\
\hline & Image & 41,7 & \\
\hline \multirow[t]{2}{*}{ Control } & Operational risk & 71,4 & 74 \\
\hline & Settlement & 76,6 & \\
\hline
\end{tabular}

